\title{
Erratum to: Morphometrical analysis of transbronchial cryobiopsies
}

Sergej Griff ${ }^{*}$, Wim Ammenwerth², Nicolas Schönfeld², Torsten T. Bauer², Thomas Mairinger' ${ }^{2}$ Torsten-Gerriet Blum², Jens Kollmeier ${ }^{2}$ and Wolfram Grüning ${ }^{2}$

\section{Erratum}

The original version of this article [1] was unfortunately missing an acknowledgments section.

The information missing from this section should have noted that this work is a part of the doctoral thesis of main author Sergej Griff, being performed at the Charité, University of Medicine in Berlin, Germany.

\section{Author details}

${ }^{1}$ Institute of Pathology, HELIOS Klinikum Emil von Behring, Berlin, Germany,

${ }^{2}$ Department of Pneumology, Lungenklinik Heckeshorn, HELIOS Klinikum

Emil von Behring, Berlin, Germany.

Received: 8 July 2016 Accepted: 12 July 2016

Published online: 19 July 2016

\section{Reference}

1. Griff S, et al. Diagnostic Pathology 2011, 6:53 DOI: 10.1186/1746-1596-6-53.

http://www.diagnosticpathology.org/content/6/1/53.

\footnotetext{
* Correspondence: sergej.griff@helios-kliniken.de

1 Institute of Pathology, HELIOS Klinikum Emil von Behring, Berlin, Germany

Full list of author information is available at the end of the article
}

Submit your next manuscript to BioMed Central and we will help you at every step:

- We accept pre-submission inquiries

- Our selector tool helps you to find the most relevant journal

- We provide round the clock customer support

- Convenient online submission

- Thorough peer review

- Inclusion in PubMed and all major indexing services

- Maximum visibility for your research

Submit your manuscript at

www.biomedcentral.com/submit 